\title{
ISOLATION AND CHARACTERIZATION OF MURAMIC ACID FROM TWO SPIROCHIETES: BORRELIA DUTTONI AND LEPTOSPIRA BIFLEXA
}

By C. D. GINGER

Department of Chemotherapy and Parasitology, National Institute for Medical Research, London, N.W.7

$\mathrm{T}$ HERE is considerable confusion about the nomen. clature and taxonomic position of helical, motile micro-organisms. Some are definitely classified with the bacteria (Spirillacea $\theta)^{1}$, others (Spirochaetales), with either the bacteria ${ }^{1}$ or the Protozoa ${ }^{2}$, and it has been suggested that certain members of the Spirochaetales should be classified with the Cyanophycore ${ }^{3}$.

One biochemical character which has proved useful in bacterial classification is the presence of cell wall mucopeptides, which on hydrolysis give a small range of sugars and amino-acids together with the amino-sugars glucosamine, galactosamine and muramic acid ${ }^{4}$. Apart from tho truo bactoria, muramic acid has been found only in the Actinomycetales ${ }^{5}$ Cyanophycer $\theta^{6}$ and Rickettsiae ${ }^{7}$. The purpose of this article is to report that muramic acid has beon isolated and charactorizod from two members of the Spirochaetales; Borrelia duttoni, the spirochæte of relapsing fever, and Leptospira biflexa, a free-living spirochæte found in natural waters.

$B$. duttoni is an old laboratory strain, maintained in young rats by syringe passage. Parasites were collected by bleeding the rats at the height of the first parasitæmia and were then separated from the blood by differential centrifugation. $L$. biflexa was cultured in Korthof's medium with added hæmoglobin, yeast extract and rabbit serum, and concentrated by centrifugation. The organisms were thoroughly washed and freeze-dried, and after extraction of lipids were treated by the method of Cummins and Harris ${ }^{8}$ for isolation of mucopeptide from cell walls. Ribonuclease digestion was replaced by extraction of ribonucleic acid with $0.3 \mathrm{~N}$ potassium hydroxide for $5 \mathrm{~h}$ at $37^{\circ} \mathrm{C}$, and deoxyribonucleic acid was extracted with 5 per cent trichloroacetic acid for $30 \mathrm{~min}$ at $70^{\circ} \mathrm{C}$. The driod residue was hydrolysed in a sealed ampoule with $4 \mathrm{~N}$ hydrochloric acid for $4 \mathrm{~h}$ at $105^{\circ} \mathrm{C}$, and dried in vacuo over potassium hydroxide. Muramic acid was identified in this hydrolysate by two-dimensional paper chromatography using $n$-butanol/pyridine/water $(6: 4: 3)$ and $n$-butanol/acetic acid/water $(63: 10: 27)$ as solvents, and spraying with ninhydrin reagent. Muramic acid was isolated from the remainder of the hydrolysate by concentration of amino-sugars on a 'Zeokarb $225\left(\mathrm{H}^{+}\right)$' column, followod by further separation of muramic acid from glucosamine on a mixed 'Norit'/'Celite' column'.

Part of the material obtained in this way was chromatographed on paper in the $n$-butanol/acetic acid/water system, together with standard preparations of glucosamine, galactosamine and synthetic muramic acid. The spirochæte material showed a spot which had the same mobility as muramic acid, and which gave positive reactions with ninhydrin and the Elson-Morgan ${ }^{10}$ reagents. The remainder of the column eluate was finally purified by preparative paper chromatography in the same solvent system, which removed other faint ninhydrin-positive spots having greater mobility than muramic acid. The purified material eluted from the paper gave a chromogen in the Rondle and Morgan reaction ${ }^{11}$ which had all the properties of the muramic acid chromogen ${ }^{12}$, that is, the absorption maximum, if read immodiately, was at $510 \mathrm{~m} \mu$ and after $24 \mathrm{~h}$ at $505 \mathrm{~m} \mu$, with an approximate two-fold increase in intensity (Fig. 1). The substituted pentose obtained by treatment of the sample with ninhydrin ${ }^{13}$ was identical in both colour and mobility with that obtained from synthetic muramic acid, when subjected to paper chromatography in $n$-butanol/pyridine/water, and sprayed with anisidine hydrochloride reagent ${ }^{14}$.

This demonstration of muramic acid in the Spirochretales suggests that they have a cell wall similar in

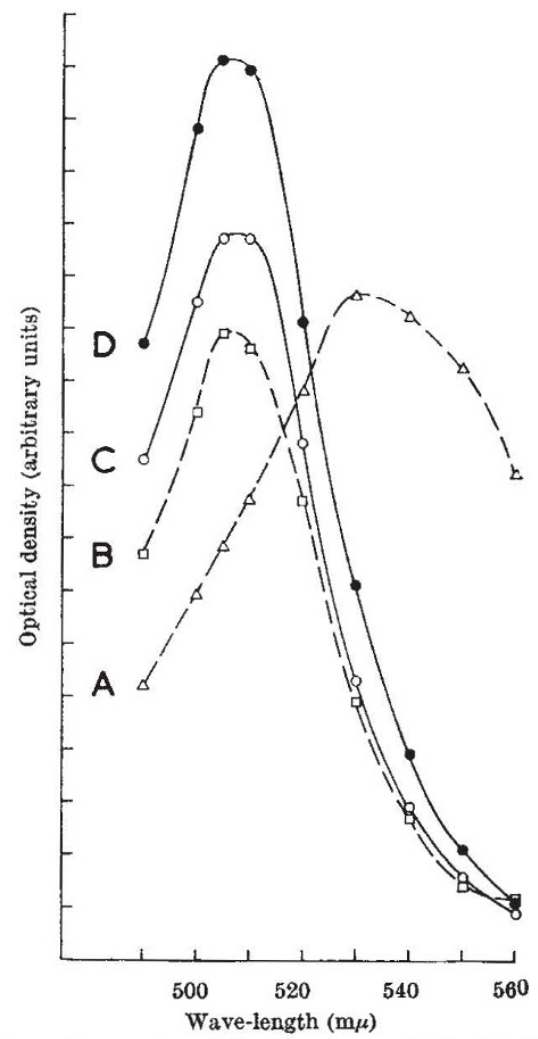

Fig. 1. Absorption spectra of the ehromogens obtained in the reactions for amino-sugars described by Rondle and Morgan 11 . $A, 20 \mu \mathrm{g}$ of glucosamine, readings taken immediately; $B, 20 \mu \mathrm{g}$ of synthetic muramic acid, readings taken after $24 \mathrm{~h} ; C$, material from $B$. duttoni, readings

structure to that of the bacteria, and provides support for their classification in this group, and not in the Protozoa. Other characters, which also point to their bacterial nature, are their general morphology, with a distinct cell wall and capsule ${ }^{15}$, resistance to nuclear staining ${ }^{16}$ and sensitivity to antibiotics ${ }^{17}$ and to lysozyme ${ }^{18}$; these last two characters are presumed to be a consequence of the muramic acid content ${ }^{4,19}$.

I thank Dr. R. H. Gigg for the synthetic muramic acid. Dr. J. D. Fulton for the two strains of spirochaetes with details of their growth, and Dr. H. R. Perkins for helpful discussion.

1 Brced, R. S., Murray, E. G. D., and Smith, N. R., Bergey's Manual of Determinative Bacteriology, seventh ed. (1957).

${ }^{2}$ Van Thiel, P. H., Acta leidensia, 30, 123 (1960).

${ }^{3}$ Lewin, R. A., Canad. J. Microbiol., 8, 555 (1962).

1 Rogers, H. J., Biochem. Soc. Symp., No. 22, 55 (1962)

5 Rogers, H. J., Biochem. Soc. Symp., No. 22, 55 (1962).

${ }^{5}$ Cummins, C. S., and Harris, H., J. Gen. Microbiol., 18, 173 (1958). rank, H., Lefort.

7 Perkins, H. R., and Allison, A. C., J. Gen. Microbiol., 30, 469 (1963).

- Cummins, C. S., and Harris, H., Gen. Microbiol., 14, 583 (1956).

- Perkins, H. R., and Rogers, H. J., Biochem. J., 72, 647 (1959).

${ }_{10}$ Partridge, S. M., and Westhall, R. G., Biochem. J., 42, 238 (1948)

11 Rondle, C. J. M., and Morgan, W. T. J., Biochem. J., 61, 586 (1955).

12 Crumpton, M. J., Biochem. J., 72, 479 (1959).

${ }^{13}$ Stoffyn, P. J., and Jeanloz, R. W., Arch. Biochem., 52, 373 (1954).

${ }^{14}$ Hough, L., Jones, J. K. N., and Wadman, W. H., J. Chem. Soc, 1702 (1950).

${ }^{15}$ Simpson, C. F., and White, F. H., J. Infect. Dis., 109, 243 (1961).

${ }^{16}$ Schlossberger, H. Jakob A., and Piekarski, G., Naturwiss., 37, 186 (1950).

17 Doak, G. O., Experimental Chemotherapy, edit. by Schnitzer, R. J., and Doak, G. O., Experimental
Hawking, F., 1 (1963)

${ }^{18}$ Sapuppo, A., Nuovi Ann. Ig., 12, 235 (1961).

${ }^{3}$ Collins, J. F., and Richmond, M. H., Nature, 195, 142 (1962). 